\title{
PENGARUH KEBIJAKAN PERUSAHAAN TERHADAP ETOS KERJA KARYAWAN DENGAN KOMPENSASI SEBAGAI VARIABEL INTERVENING (Studi Kasus Karyawan KAP Drs. Chandra Dwiyanto di Surabaya)
}

\author{
Rina Maretasari \\ Fakultas Ekonomi Universitas Muhammadiyah Surabaya \\ e-mail: rina_mareta@yahoo.com \\ Fitri Nuraini \\ Fakultas Ekonomi Universitas Muhammadiyah Surabaya \\ e-mail: ftr_account@yahoo.com
}

\begin{abstract}
The existence of the theory of compensation from Dessler in the concept of factors that affect compensation are 3 factors: internal organization, personal employees and external companies. In this case the internal factor of the organization which includes the funds of the organization and the union, the union is an example of one company policy that can affect employee work ethic. If the company's policy of overtime, salary increases and holiday allowances (THR) in accordance with the provisions of the Workers Act, indirectly can improve employee performance spirit. Based on the compensation theory, this study tries to test the indirect relationship between company policy and employee work ethic by entering the compensation variable as intervening variable.

The population of this research is all employees of Public Accountant Firm Chandra, amounting to 41 people. This research uses quantitative research method with Path Analysis analysis technique whose test is done with software SPSS 13.0 The result of the analysis concludes that compensation as intervening variable mediates to the influence of company policy on employee work ethic. Based on these results, the hypothesis of this study is evident.
\end{abstract}

Keywords: company policy, work ethic, compensation

\section{PENDAHULUAN}

Perusahaan merupakan organisasi yang didirikan oleh seseorang atau sekelompok orang atau badan lain yang kegiatannya melakukan produksi dan distrubusi guna memenuhi kebutuhan ekonomis manusia. Setiap perusahaan tentunya mempunyai kebijakan yang dapat mempengaruhi perusahaan itu sendiri umumnya dan karyawan secara khususnya.Dalam teori perusahaan peranan stakeholders dirasa sangatlah penting untuk kemanjuan perusahaan baik internal maupun eksternal.

Setiap perusahaan baik perusahaan kecil, menengah dan besar memilki kebijakan,misal kebijakan dalam hal keselamatan dan kesehatan kerja, cuti dan waktu tidak bekerja karyawan, gaji, tunjangan, kesehatan dan lain sebagainya. Kebijakan tersebut tentunya diberikan untuk meningkatkan kesejahteraan karyawanya, sehingga peranan kebijakan perusahaan dianggap mempengaruhi kinerja karyawan.Pada hakekatnya kebijakan meliputi 5 pertanyaan, antara lain what, why, who, where, dan how. Kelima pertanyaan itu menyangkut tentang masalah yang dihadapi oleh suatu lembaga yaitu dalam pengambilan keputusan yang mencakup antara lain isi, cara atau prosedur yang ditentukan, strategi, waktu keputusan. (http://infodanpengertian.blogspot.co.id/2015/04/p engertian-kebijakan-menurut-para-ahli.html.

Kebijakan yang diberikan oleh perusahaan ditujukan untuk meningkatkan etos kerja karyawan sehingga karyawan dapat memberikan loyalitasnya. Etos kerja merupakan semangat kerja yang menjadi ciri khas dan keyakinan seseorang atau kelompok. Menurut A. Tabrani Rusyan, fungsi etos kerja yaitu pendorong timbulnya perbuatan, pendorong aktivitas, dan penggerak. (https://badriah27.wordpress.com/2012/11/07/buda ya-kerja-etos-kerja/. Kebijakan adalah ucapan atau tulisan yang memberikan petunjuk umum tentang penetapan ruang lingkup dalam memberikan batas dan arah kepada seseorang untuk bermotivasi. 
Lingkungan yang baik merupakan salah satu faktor dalam mempengaruhi etos kerja (Affandi: 76,2016). Semakin baik lingkungan kerja maka semakin meningkat etos kerja dan loyalitas karyawan. Etos merupakan kecenderungan atau karakter, sikap, kebiasaan, yang berbeda dari individu ataupun kelompok. Dan dapat dikatakan bahwa etos pada dasarnya adalah etika. Masyarakat dan bangsa manapun mempunyai etika; dan ini merupakan nilai-nilai yang universal. Nilai-nilai etika yang dikaitkan dengan etos kerja misalnya rajin, bekerja keras, displin tinggi, ulet, tekun dan nilai-nilai etika lainnya. (http://www.putra-putri-indonesia.com/pengertianetos-kerja.html).

Penelitian Sari (2012) tentang etos kerjadipengaruhi oleh disiplin kerja, salah satu ciri disiplin kerja adalah ketaatan. Ketaatan merupakan bagian dari kebijakan perusahaan,jika karyawan taat akan kebijakan perusahan maka secara tidak langsung karyawan akan memberikan yang terbaik untuk perusahaan termasuk semangat kerja, loyalitas, dan lain sebagainya (menurut Sinungan dalam penelitian Sari, 2012). Menurut Suryaningrat dalam penelitian sari (2012) tentang faktor yang mempengaruhi etos kerja antara lain keuletan, disiplin kerja, sikap inovatif, kreatifitas kerja dan sikap altruistic (rendah diri).

Kompensasi adalah semua pendapatan yang berbentuk uang, barang langsung atau tidak langsung yang diterima karyawan sebagai imbalan atas jasa yang diberikan kepada perusahaan (Malayu S.P. Hasibuan, 2002:54). Kompensasi bisa dalam bentuk uang, artinya gaji dibayar dengan sejumlah uang kartal kepada karyawan yang bersangkutan (http://www.kajianpustaka.com/2012/10/pengertia n-jenis-dan-tujuan-kompensasi.html). Dengan adanya kompensasi maka mendorong kompensasi karyawan untuk bekerja, dan tentunya kompensasi yang diberikan sesuai dengan prestasi kerja , kinerja karyawan serta loyalitas karyawan. Sistem kompensasi mempunyai tiga komponen pokok antara lain upah dasar, upah berdasar kinerja dan upah tidak langsung. (http://jurnalsdm.blogspot.co.id/2009/07/teori-

kompensasi.html)

Pada penelitian ini akan menguji pengaruh kebijakan perusahaan terhadap etos kerja karyawan dengan kompensasi sebagai variabel intervening. Dalam kaitannya dengan variabel intervening, peneliti dalam hal ini memilih kompensasi sebagai variabel yang secara tidak langsung mempengaruhi variabel independen terhadap variabel dependen.
Peneliti memilih kompensasi sebagai variabel intervening karena secara teoritis kompensasi merupakan salah satu sarana terpenting dalam membentuk perilaku dan mempengaruhi kinerja karyawan.

sdm.blogspot.co.id/2009/07/teorikompensasi.html)

Adanya teori kompensasi menurut Gary Dessler dalam konsep faktor yang mempengaruhi kompensasi antara lain intern organisasi, pribadi karyawan dan eksternal perusahaan. Dalam hal ini faktor intern organsasi mencakup dana organisasi dan serikat pekerja, serikat pekerja merupakan salah satu contoh kebijakan perusahaan yang dapat mempengaruhi etos kerja karyawan. Jika kebijakan perusahaan tentang adanya lembur, kenaikan gaji dan tunjangan hari raya (THR) sesuai dengan ketentuan UU pekerja maka secara tidak langsung dapat meningkatkan kinerja karyawan.

Melalui teori kompensasi, maka dapat diketahui faktor - faktor kondisional apa saja yang berperan dalam memperjelas atau mempengaruhi kebijakan perusahaan terhadap etos kerja karyawan. Berdasarkan teori kompensasi tersebut, penelitian ini mencoba untuk menguji hubungan tidak langsung antara kebijakan perusahaan dengan etos kerja karyawan dengan memasukkan variabel kompensasi sebagai variabel intervening.

Oleh sebab itu dengan perubahan dalam kebijakan perusahaan dapat mempengaruhi etos kerja karyawan, sehingga kompensasi akan menjadi variabel yang dapat memperjelas atau mempengaruhi hubungan antara kebijakan perusahaan dan etos kerja karyawan. Salah satu contoh jika kebijakan perusahaan dapat memberikan karyawan suatu kesejahteraan, kenyamanan termasuk pemberian kompensasi dan secara tidak langsung maka etos kerja karyawan meningkat.

Penelitian ini nantinya menggali lebih dalam mengenai pengaruh kebijakan perusahaan terhadap etos kerja karyawan dengan kompensasi sebagai variabel intervening. Sebelumnya penelitian yang pernah dilakukan terkait dengan kebijakan perusahaan serta etos kerja karyawan adalah Nashar (2012), Fakhri (2015), Retnosari et. al. (2016), Nurcahyani et. al (2016), dan Sari (2012) yang menunjukkan bahwa etos kerja karyawan sebagai tolak ukur kebijakan perusahaan baik perusahaan swasta, negeri maupun asing. Dan penelitian ini berfokus pada etos kerja karyawan ini yang ditekankan pada pengaruh kebijakan perusahaan dengan kompensasi sebagai intervening. 
Berdasarkan latar belakang di atas, penulis ingin melakukan penelitian dengan judul :'Pengaruh Kebijakan Perusahaan Terhadap Etos Kerja Karyawan Dengan Kompensasi Sebagai Variabel Intervining (Studi Kasus Karyawan pada KAP Drs. Chandra Dwiyanto di Surabaya).

\section{Rumusan Masalah}

Berdasarkan latar belakang yang di atas, maka masalah dalam penelitian ini dapat dirumuskan :

1. Apakah terdapat pengaruh kebijakan perusahaan terhadap kompensasi?

2. Apakah terdapat pengaruh kompensasi terhadap etos kerja karyawan?

\section{Kerangka Teoritis Dan Perumusan Hipotesis Kebijakan}

- Menurut Lasswell (1970): kebijakan adalah suatu program pencapaian tujuan, nilai-nilai dan praktik-praktik yang terarah (a projected program of goals values and practices).

- Menurut Anderson (1979): kebijakan adalah serangkaian tindakan yang mempunyai tujuan yang harus diikuti dan dilakukan oleh para pelakunya untuk memecahkan suatu masalah ( $a$ purposive corse of problem or matter of concern).

- Menurut Heclo (1977): kebijakan adalah cara bertindak yang sengaja dilaksanakan dalam menyelesaikan masalah-masalah.

- Menurut Eulau (1977): kebijakan adalah keputusan tetap, dicirikan oleh suatu tindakan yang berkelanjutan dan berulang-ulang pada mereka yang membuat dan melaksanakan kebijakan.

- Menurut Amara Raksasa Taya (1976): kebijakan adalah suatu strategi yang diarahkan untuk mencapai tujuan.

- Menurut Friedrik (1963): kebijakan adalah tindakan yang diajukan seseorang, group, dan pemerintah dalam lingkungan tertentu dengan mencantumkan kendala-kendala yang dihadapi serta kesempatan yang memungkingkan pelaksanaan usulan tersebut dalam upaya mencapai tujuan.

- Menurut Budiardjo (1988): kebijakan adalah keputusan yang diambil oleh seorang pelaku atau kelompok politik dalam usaha untuk memilih tujuan dan cara mencapai tujuan tersebut.

- Menurut Carter V. Good (1959): kebijakan adalah sebuah pertimbangan yang didasarkan atas suatu nilai dan beberapa penilaian terhadap faktor yang bersifat situasional, untuk mengoperasikan perencanaan yang bersifat umum dan memberikan bimbingan dalam pengambilan keputusan demi tercapainya suatu tujuan.

- Menurut Indrafachrudi (1984): kebijakan adalah ketentuan pokok yang menjadi dasar dan arah dalam melaksanakan kegiatan administrasi.

- Menurut Carl Friedrich: Kebijakan adalah tindakan yang mengarah pada tujuan dalam lingkungan tertentu sehubungan dengan adanya hambatan untuk mencari peluang dala mencapai tujuan yang diinginkan. http://www.pengertianahli.com/2014/08/penger tian-kebijakan-menurut-para-ahli.html

Dari penjelasan pengertian kebijakan dapat disimpulkan adalah suatu tindakan untuk mencapai tujuan dan menyelesaikan masalah serta mewujudkan sasaran yang diinginkan.

Teori kebijakan, antara lain:

1. Teori Kelembagaan memandang kebijakan sebagai aktivitas kelembagaan dalam struktur dan lembaga pemerintah.

2. Teori Kelompok yang memandang kebijakan sebagai keseimbangan kelompok yang tercapai dalam perjuangan kelompok pada suatu saat tertentu.

3. Teori Elit memandang Kebijakan pemerintah sebagai suatu nilai-nilai kelompok elit yang memerintahkan.

4. Teori Rasional memandang kebijakan sebagai pencapaian tujuan secara efisien melalui sistem pengambilan keputusan yang tetap.

5. Teori Inkremental, kebijakan dipandang sebagai variasi terhadap kebijakan masa lampau atau kebijakan pemerintah yang ada sekarang merupakan kelanjutan kebijakan pemerintah pada waktu yang lalu.

6. Teori Permainan memandang kebijakan sebagai pilihan yang rasional dalam situasi yang saling berkompetisi.

7. Teori kebijakan yang lain adalah Teori Campuran yang merupakan gabungan dari model rasional komprehensif dan inkremental. http://wahyudianto-

eko.blogspot.co.id/2011/01/teori-

kebijakan.html

Dari penjelasan diatas disimpulkan bahwa teori yang mendasari kebijakan yaitu pencapaian tujuan dengan struktur dan lembaga pemerintah yang merupakan pusat kebijakan politik dalam pengambilan keputusan. 


\section{Perusahaan}

\section{- Menurut Murti Sumarni (1997)}

Perusahaan adalah unit kegiatan produksi yang mengolah sumber daya ekonomi untuk menyediakan barang dan jasa bagi masyarakat dengan tujuan memperoleh keuntungan dan memuaskan kebutuhan masyarakat.

\section{- Menurut Much Nurachmad}

Perusahaan adalah bentuk usaha yang berbadan hukum atau tidak, milik orang perseorangan, milik persekutun, atau milik badan hukum, baik milik swasta ataupun milik negara yang memperkerjakan pekerja dengan cara membayar upah atau imbalan dalam bentuk lain.

- Menurut pendapat Swastha dan Sukotjo (2002 : 12)

Definisi perusahaan adalah organisasi produksi yang menggunakan dan mengkoordinir sumber ekonomi untuk memuaskan kebutuhan dengan cara yang menguntungkan.

\section{- Menurut pendapat Kansil (2001 : 2)}

Pengertian perusahaan adalah bentuk badan usaha yang menjalankan setiap jenis usaha yang bersifat tetap dan didirikan, serta berkedudukan dalam wilayah negara indonesia untuk tujuan memperoleh keuntungan.

\section{- Menurut Ebert dan Griffin}

Perusahaan adalah organisasi yang menghasilkan barang dan jasa untuk mendapatkan keuntungan.

\section{- Menurut Prof. Mr. W.L.P.A. Molengraff}

Dari sudut padang ekonomi, perusahaan adalah perbuatan yang dilakukan dengan secara berkelanjutan, untuk mendapatkan penghasilan dengan cara memperdagangkan barang atau mengadakan perjanjian perdagangan. http://definisibisnismenurutparaahli.blogspot.co .id/2016/09/10-definisi-perusahaan-menurutpara-ahli.html

Dari penjelasan pengertian perusahaan dapat disimpulkan bentuk badan usaha yang menghasilkan barang dan jasa dengan tujuan memperoleh keuntungan dan memuaskan kebutuhan masyarakat.

\section{Kebijakan Perusahaan}

Kebijakan pada hakekatnya studi yang mencakup pertanyaan: what, why, who, where, dan how. Semua pertanyaan mencakup tentang masalah yang dihadapi oleh lembaga yang mengambil keputusan meliputi; isi, prosedur yang ditentukan, strategi, waktu keputusan yang diambil dan dilaksanakan.

http://infodanpengertian.blogspot.co.id/2015/04/pe

ngertian-kebijakan-menurut-para-ahli.html

Tahap-tahap kebijakan publik menurut William Dunn adalah sebagai berikut:

1. Penyusunan Agenda

Agenda setting adalah sebuah fase dan proses yang strategis dalam realitas kebijakan publik. Dalam proses inilah memiliki ruang untuk memaknai apa yang disebut sebagai masalah publik dan prioritas agenda publik dikompetisikan. Dalam agenda setting sangat penting untuk menentukan isu publik yang akan diangkat dalam agenda pemerintah. Policy issues sering disebut sebagai masalah kebijakan (policy problem). Policy issues biasanya muncul karena terjadi silang pendapat mengenai arah dan tindakan yang telah ditempuh, atau pertentangan pandangan mengenai karakter permasalahan. Menurut William Dunn (1990), isu kebijakan merupakan fungsi dari adanya perdebatan tentang rumusan, rincian, penjelasan maupun penilaian atas suatu masalah. Namun tidak semua isu bisa masuk menjadi suatu agenda kebijakan.

Ada beberapa kriteria isu yang bisa dijadikan agenda kebijakan publik (Kimber, 1974; Salesbury 1976; Sandbach, 1980; Hogwood dan Gunn, 1986) diantaranya:

a. telah mencapai titik kritis, jika diabaikan akan menjadi ancaman yang serius;

b. telah mencapai tingkat partikularitas tertentu akan berdampak dramatis;

c. menyangkut emosi dari sudut kepentingan umum;

d. menjangkau resiko yang amat luas;

e. mempermasalahkan kekuasaan dalam masyarakat;

f. menyangkut persoalan yang fasionable.

Penyusunan agenda kebijakan seharusnya dilakukan berdasarkan tingkat urgensi suatu kebijakan, yang juga melibatkan stakeholder.

2. Adopsi/ Legitimasi Kebijakan

Tujuan legitimasi adalah untuk memberikan suatu otorisasi pada proses pemerintahan. Jika tindakan legitimasi dalam suatu masyarakat diatur oleh kedaulatan rakyat, maka warga negara akan mengikuti arahan pemerintah. Namun warga negara harus percaya bahwa tindakan pemerintah itu sah.

\section{Penilaian/ Evaluasi Kebijakan}

Secara umum evaluasi kebijakan dapat dikatakan sebagai suati kegiatan yang mencakup penilaian kebijakan meliputi substansi, implementasi dan dampak. Dalam hal ini, evaluasi 
dipandang sebagai kegiatan yang fungsional. Artinya, evaluasi kebijakan tidak hanya dilakukan pada tahap akhir saja, melainkan dilakukan dalam seluruh proses suatu kebijakan. Perlu kita ketahui mengapa kita harus mengetahui serta memahami setiap kebijakan yang ada, karena kebijakan tidak bisa dipahami secara tekstual, namun banyak sekali hal-hal yang secata kontekstual yang tidak diketahui oleh publik dalam menetapkan kebijakan. Dan peran media sebagai fasilitator untuk tranformasi informasi kepada rakyat, maka haruslah setiap media yang ada bersifat independen Selain media sebagai alat, masyarakat juga berperan untuk menganalisis setiap kebijakan dan membantu menyusun kebijakan yang ada.

Ada 2 akibat yang timbul dari penetapan kebijakan, yaitu: kebijakan yang berorientasi pada pelayanan publik. Dalam arti sesuai dengan makna demokrasi dan kebijakan yang ditetapkan hanya untuk kepentingan beberapa kalangan saja. Kebijakan dapat diwujudkan dengan cara; pembuatan peraturan UU, perencanaan kegiatan, aneka intervensi terhadap ekonomi/sosial masyarakat.

\section{Kebijakan Etik}

Kebijakan etik adalah suatu peraturan yang dibuat oleh suatu kelompok untuk mengatur perilaku anggotanya menjadi lebih baik. Ada beberapa tujuan dari kebijakan etik antara lain :

1. Untuk mengkontrol moral dalam kelompok.

2. Supaya kita mengetahui bagaimana menyikapi kebijakan yang di terapkan oleh pemerintah.

3. Untuk memberi petunjuk kepada anggotanya.

Dari penjelasan diatas dapat disimpulkan bahwa tahapan dalam kebijakan publik diantaranya penyusunan agenda, formulasi kebjiakan, legitimasi dan evaluasi kebijakan. Kebijakan publik dapat diwujudkan termasuk perencanaan kegiatan dalam pemberian tunjangan, kesehatan, cuti, penerimaan dan pemberhentian karyawan dan lain sebagainya.

http://wahyudiantoeko.blogspot.co.id/2011/01/teori-kebijakan.html

\section{Etos}

Etos adalah aspek evaluatif sebagai sikap yang mendasar terhadap diri yang direfleksikan dalam kehidupan. (Khasanah, 2004:8). Menurut Geertz (1982:3) Etos adalah sikap yang mendasar terhadap diri dan dunia yang dipancarkan dalam kehidupan. Sikap disini digambarkan sebagai suatu prinsip individu yang sudah menjadi keyakinan dalam pengambilan keputusan.
Menurut kamus Webster, etos didefinisikan sebagai suatu keyakinan yang berfungsi sebagai panduan tingkah laku bagi seseorang, sekelompok, atau suatu institusi (guiding beliefs of a person, group or institution).

Penjelasan pengertian etos dapat disimpulkan yaitu karakter yang mendasar terhadap diri dan dunia yang direfleksikan dalam kehidupan. http://jurnal-sdm.blogspot.co.id/2010/10/etos-

kerja-definisi-fungsi-dan-cara.html

\section{Etos Kerja}

Menurut Usman Pelly (1992:12), etos kerja adalah sikap yang muncul atas kehendak dan kesadaran sendiri yang didasari oleh sistem orientasi pada nilai budaya terhadap kerja. Dengan pengertian bahwa etos kerja mempunyai dasar dari nilai budaya, dan nilai budaya tersebut yang membentuk etos kerja masing-masing pribadi.

Etos kerja dapat diartikan sebagai konsep tentang kerja atau paradigma kerja yang diyakini oleh seseorang atau sekelompok orang yang diwujudkan melalui perilaku kerja (Sinamo, 2003, 2). Menurut Toto Tasmara, (2002) Etos kerja adalah totalitas kepribadian dirinya dan caramengekspresikan, memandang, meyakini dan memberikan makna atasa sesuatu yang mendorong dirinya untuk bertindak secara optimal. http://jurnal-sdm.blogspot.co.id/2010/10/etos-

kerja-definisi-fungsi-dan-cara.html

Penjelasan pengertian etos kerja dapat disimpulkan yaitu totalitas kepribadian seseorang dalam bertindak yang ditunjukkan melalui perilaku kerja.

\section{Tujuan Etos Kerja}

Tujuan etos kerja dapat disebutkan, yaitu: (1) sebagai penjamin hasil kerja dengan kualitas yang lebih baik, (2) membuka komunikasi antar sesama pegawai/karyawan, (3) meningkatkan kesadaran dan penyesuaian diri, dan (4) meningkatkan kualitas, efisiensi dan efektivitas kerja sehingga meminimalisir kesalahan dalam bekerja (M. Yusron, Etos Kerja Personalia Pendidikan;Tela'ah terhadap Kinerja Personalia Pendidikan di Indonesia, diakses 22 September 2011).

\section{Prinsip-prinsip Etos Kerja} berikut:

Prinsip-prinsip etos kerja diantaranya sebagai

1. Commitment, yakni memiliki niat yang kuat dan tidak ada kata menyerah dalam menghadapi suatu tantangan. 
2. Confidence, yakni percaya diri, memiliki keberanian untuk pengambilan keputusan dan berani menerima segala resiko.

3. Cooperative, yakni terbuka dan kerja sama dalam mengembangkan diri.

4. Care, yakni sangat perhatian terhadap segala hal meskipun hal-hal yang bersifat kecil.

5. Creative, selalu mencari terobosan pada halhal yang baru.

6. Challenge, yakni hambatan merupakan sebuah tantangan yang harus dihadapi untuk diselesaikan.

7. Calculation, yakni tindakan dan keputusan yang harus dipertimbangkan secara objektif dan faktual secara teratur.

8. Communication, yakni selalu menjalin komunikasi dan memperbanyak jaringan kerja (net working).

9. Competiveness, yakni senang berkompetisi sebagai dasar untuk menjadi orang yang terbaik. Demikian juga sebagai dasar untuk selalu berintropeksi, mencari kelemahan dan kekurangan dan segera mencari solusinya.

10. Change, yakni tidak takut terhadap perubahan, bahkan memiliki perasaan senang terhadap perubahan (spirit of change). Sadar bahwa dunia ini tidak abadi, segala sesuatu akan berubah dan mengalir (M. Yusron, Etos Kerja Personalia Pendidikan;Tela'ah terhadap Kinerja Personalia Pendidikan di Indonesia, diakses 22 September 2011). http://nasihatbathin.blogspot.co.id/2011/12/et os-kerja-pegawai.html

Usaha-usaha yang perlu dikembangkan dalam meningkatkan kualitas etos kerja, di antaranya:

1. Pembinaan disiplin

Pemegang kebijakan diklat harus selalu memupuk dan mampu menumbuhkan disiplin bagi karyawan/pegawai, terutama disiplin diri.

2. Pemberian kompensasi

Setiap karyawan/pegawai memiliki karakteristik, yang satu sama lain boleh jadi berbeda. Hal ini memerlukan perhatian khusus dari pemegang kebijakan agar mereka dapat memanfaatkan waktu untuk meningkatkan kinerjanya.

3. Pemberian penghargaan (reward)

Penghargaan sangat penting dalam upaya menumbuhkan etos kerja dan meningkatkan kinerja. Dan melalui penghargaan ini bertujuan untuk meningkatkan kinerja yang positif dan produktif.

4. Persepsi
Persepsi adalah proses seseorang untuk mengetahui beberapa hal melalui panca indera. Persepsi yang baik dimiliki oleh pegawai akan menumbuhkan iklim kerja yang kondusif dan sekaligus akan meningkatkan kualitas produktivitas kerja (M. Yusron, Etos Kerja Personalia Pendidikan; Tela'ah terhadap Kinerja Personalia Pendidikan di Indonesia, diakses 22 September 2011).

\section{Kompensasi}

Kompensasi adalah total suatu imbalan yang diterima para karyawan sebagai pengganti jasa yang telah diberikan. Tujuan pemberian kompensasi adalah untuk menarik, mempertahankan dan memotivasi karyawan. (Mondy, 2008).

Jenis-jenis Kompensasi

1. Kompensasi finansial secara langsung terdiri dari bayaran yang diterima seseorang dalam bentuk upah, gaji, komisi dan bonus.

2. Kompensasi finansial tidak langsung (tunjangan) meliputi seluruh imbalan finansial yang tidak termasuk dalam kompensasi financial langsung.

3. Kompensasi non finansial, meliputi kepuasan yang diterima seseorang dari pekerjaan itu sendiri atau dari lingkungan psikolologis dan/atau fisik tempat orang tersebut bekerja. (Mondy, 2008).

Sistem kompensasi non financial dikembangkan oleh manajemen kompensasi akan memuaskan kebutuhan individu atas tantangan, tanggungjawab, keberagaman, pengaruh dalam pengambilan keputusan, pengembangan ketrampilan. Manajemen kompensasi merupakan proses pengembangan dan penetapan strategi, kebijakan, serta sistem kompensasi yang membantu organisasi untuk mencapai sasarannya dengan mendapatkan dan mempertahankan orang yang diperlukan dan dengan meningkatkan motivasi serta komitmen mereka (Kadarisman,2 012).

\section{Teori Kompensasi}

Menurut teori kompensasi "Gary Dessler, dalam pemberian kompensasi, terdapat beberapa faktor yang mempengaruhinya. Secara garis besar faktor-faktor tersebut terbagi dalam tiga, antara lain faktor intern organisasi, pribadi karyawan yang bersangkutan, dan faktor ekstern pegawai organisasi.

a. Faktor Intern Organisasi 
Contoh faktor intern organisasi meliputi dana organsasi, dan serikat pekerja.

b. Faktor Pribadi Karyawan

Contoh faktor pribadi karyawan antara lain produktifitas kerja, posisi dan jabatan, pendidikan dan pengalaman serta jenis dan sifat pekerjaan.

c. Faktor Ekstern

Contoh faktor ekstern pegawai dan organisasi mencakup penawaran dan permintaan kerja, biaya hidup, kebijaksanaan pemerintah, kondisi perekonomian nasional.

\section{Kebijakan Perusahaan}

Kebijakan pada hakekatnya studi tentang policy (kebijakan) mencakup pertanyaan: what, why, who, where, dan how. Semua pertanyaan mencakup tentang masalah yang dihadapi lembaga dalam pengambilan keputusan yang meliputi isi, prosedur yang ditentukan, strategi, dan waktu keputusan.

http://infodanpengertian.blogspot.co.id/2015/04/pe ngertian-kebijakan-menurut-para-ahli.html

Kebijakan perusahaan dapat berupa kebijakan pemberian gaji, tunjangan, cuti, penerimaan dan pemberhentian karyawan dan lain sebagainya. Hasil penelitian Nashar (2014) menyatakan bahwa kebijakan perusahaan dalam hal penempatan pegawai dipengaruhi oleh kesesuaian pendidikan, ketrampilan dan pengalaman kerja. Diantara 3 faktor tersebut yang paling dominan berpengaruh terhadap kebijakan penempatan pegawai. Hal ini dikarenakan bahwa ketrampilan masing-masing pegawai berbeda disesuaikan dengan kinerja pegawai ,misal ketrampilan dalam hal menghitung lebih sesuai dengan posisi staf akuntansi atau staf pajak, ketrampilan dalam hal mengetik sesuai dengan posisi staf administrasi dan lain sebagainya.

$H_{1}$ : Kebijakan Perusahaan Berpengaruh Secara Signifikan Terhadap Kompensasi.

\section{Kompensasi}

Kompensasi adalah semua pendapatan dalam bentuk uang, barang langsung atau tidak langsung yang diterima karyawan sebagai imbalan atas jasa yang diberikan kepada perusahaan (Malayu S.P. Hasibuan, 2002:54). Kompensasi dalam bentuk uang, yang artinya gaji dibayar dengan sejumlah uang kartal kepada karyawan yang bersangkutan. http://www.kajianpustaka.com/2012/10/pengertian -jenis-dan-tujuan-kompensasi.html

Tujuan pemberian kompensasi antara lain menghargai prestasi karyawan, menjamin keadilan gaji karyawan, mempertahankan karyawan atau mengurangi perputaran karyawan, memperoleh karyawan yang berkualitas, pengendalian biaya dan memenuhi peraturan-peraturan. http://www.kajianpustaka.com/2012/10/pengertian -jenis-dan-tujuan-kompensasi.html

Hasil penelitian Retnosari (2016) serta Nurcahyani dan Adnyani (2016) menyatakan bahwa kompensasi berpengaruh positif terhadap kinerja karyawan. Dalam hal ini kompensasi merupakan kontribusi kepada perusahaan untuk karyawan yang dievaluasi dari kinerja karyawan. Kinerja karyawan dapat berupa loyalitas, disiplin dan semangat kerja yang bisa memajukan perusahaan, untuk kompensasi sendiri bisa berupa pemberian dalam bentuk finansial maupun non finansial.

$\mathrm{H}_{2}$ : Kompensasi Berpengaruh Secara Signifikan Terhadap Etos Kerja Karyawan

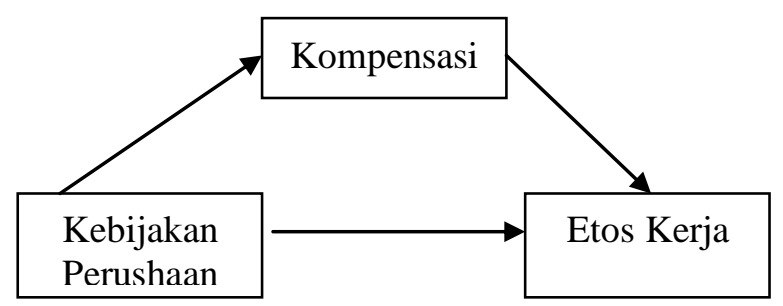

\section{Gambar 1 \\ Kerangka Penelitian}

\section{METODE PENELITIAN}

Definisi Operasional dan Pengukuran Variabel

Definisi Operasional dan Pengukuran Variabel dalam penelitian ini:

\section{Kebijakan Perusahaan}

Kebijakan pada hakekatnya studi tentang policy (kebijakan) mencakup pertanyaan : what, why, who, where, dan how. Semua pertanyaan tentang masalah yang dihadapi lembaga lembaga yang mengambil keputusan yang meliputi ; isi, prosedur yang ditentukan, strategi, waktu keputusan.

http://infodanpengertian.blogspot.co.id/2015/04/pe ngertian-kebijakan-menurut-para-ahli.html

Instrumen penelitian dikembangkan oleh Nashar (2012) terdiri atas 10 item pertanyaan, yang telah dimodifikasi oleh peneliti.

\section{Etos Kerja}

Menurut Usman Pelly (1992:12), etos kerja adalah suatu sikap yang timbul atas kehendak dan kesadaran sendiri yang didasarkan oleh sistem orientasi nilai budaya terhadap kerja. http://jurnal- 
$\underline{\text { sdm.blogspot.co.id/2010/10/etos-kerja-definisi- }}$ fungsi-dan-cara.html

Instrumen penelitian dikembangkan oleh Sari (2012) terdiri atas 10 item pertanyaan, yang telah dimodifikasi oleh peneliti. Dan menurut Mydral (dalam Suseno, 1999:123) ada dua belas etos kerja yang dianggap perlu dalam menyukseskan pembangunan yaitu 1) Efisien; 2) Kejujuran; 3) Sikap tepat waktu; 4) Kesederhanaan; 5) Kerajinan; 6) Mengikuti rasio dalam mengambil keputusan dan tindakan; 7) Sikap bekerja sama; 8) Sikap bersandar pada kekuatan sendiri; 9) Sikap mau berkerja sama; 10) Kesediaan untuk berubah; 11) Kegesitan dalam mempergunakan kesempatan; dan 12) Kesediaan memandang jauh ke depan.

\section{Kompensasi}

Kompensasi adalah semua pendapatan dalam bentuk uang, barang langsung atau tidak langsung yang diterima karyawan sebagai imbalan atas jasa yang diberikan kepada perusahaan (Malayu $\quad$ S. $\quad$ P. $\quad$ Hasibuan, 2002:54).http://www.kajianpustaka.com/2012/10/p engertian-jenis-dan-tujuan-kompensasi.html

Instrumen penelitian dikembangkan oleh Penggabean (2002:92) yang terdiri atas:

1) Kelayakan gaji

2) Upah yang diperoleh tiap bulan

3) Pemenuhan kebutuhan primer

4) Pemenuhan kebutuhan sekunder

5) Kepuasan terhadap upah

Satuan yang digunakan dalam variabel penelitian adalah skala Likert. Dengan bobot nilai jawaban kuisioner responden berdasarkan skala Likert. Berikut bobot nilai jawaban kuisioner responden berdasarkan skala likert:

Sangat Setuju 5

Setuju 4

Ragu - ragu 3

Tidak Setuju 2

Sangat Tidak Setuju $\quad 1$

\section{Populasi dan Sampel}

Populasi dari penelitian ini adalah staf karyawan Kantor Akuntan Publik Chandra sesuai data yang diperoleh dari bagian personalia Kantor Akuntan Publik Chandra, jumlah staf karyawan Kantor Akuntan Publik Chandra sebanyak 41 karyawan.

Sampel ditentukan dengan teknik convenience sampling yang bersifat nonprobability. Dalam penelitian ini yang menjadi populasi adalah seluruh karyawan yang berjumlah 41 orang. Berdasarkan pertimbangan diatas maka populasi dalam penelitian ini bertindak pula sebagai sampel. Penelitian ini menggunakan metode penelitian populatif (sensus) atau sampling jenuh yakni cara pengumpulan data yang mengambil seluruh elemen populasi diselidiki satu per satu (Supranto, 2008:23).

\section{Jenis Data dan Sumber Data}

Data primer ini diperoleh dari kuisioner yang diberikan kepada responden, dalam hal ini adalah staf karyawan Kantor Akuntan Publik Chandra yang dijadikan sampel penelitian. Kuisioner didesain dengan menggunakan skala likert dengan lima alternatif pernyataan.

Data sekunder diperoleh dari bagian personalia Kantor Akuntan Publik Chandra dan keterangan lain yang berkaitan dengan data yang dibutuhkan.

\section{Uji Validitas}

Sebuah instrumen memiliki validitas tinggi apabila butir-butir yang membentuk instrumen tidak menyimpang dari fungsi instrumen tersebut. Menurut Ghozali $(2013,53)$ syarat minimum agar suatu butir dapat dianggap valid jika diperoleh nilai $r$ hitung $>r$ table.

\section{Uji Reliabilitas}

Uji reliabilitas ini menggunakan reliabilitas konsistensi internal yaitu teknik cronbach Alpha $(\alpha)$. Apabila nilai cronbach Alpha dari hasil pengujian > 0.70 maka dapat dikatakan bahwa konstruk atau variabel itu adalah reliable (Ghozali: 2013,48).

\section{Uji Normalitas}

Bertujuan untuk menguji apakah dalam model regresi variabel dependen dan independen keduanya mempunyai distribusi normal atau tidak. Uji normalitas ini menggunakan Normalitas $P$-Plot of regression standardized residual terhadap pengujian pada keseluruhan variabel dalam penelitian ini. Uji normalitas data dilihat dengan melihat pola pada kurva penyebaran pada grafik PPlot. Jika pola penyebaran memiliki garis normal kurva maka dapat dikatakan data distribusi normal.

\section{Teknik Analisis dan Uji Hipotesis}

Analisis regresi linier berganda bertujuan untuk menguji hipotesis tentang pengaruh antar variabel secara parsial. Analisis ini digunakan untuk menganalisis pengaruh antara variabel 
independen $(\mathrm{X})$ yaitu kebijakan perusahaan (X) terhadap variabel dependen yaitu etos kerja karyawan (Y) dimediasi oleh variabel mediator yaitu kompensasi (Z). Model penelitian yang digunakan adalah:

Persamaan 1:

$\mathrm{Z}=\alpha+\mathrm{b}_{1} \mathrm{X}+\mathrm{e}_{1}$

Persamaan 2:

$\mathrm{Y}=\alpha+\mathrm{b}_{2} \mathrm{Z}+\mathrm{b}_{1} \mathrm{X}+\mathrm{e}_{2}$

Dimana:

$\mathrm{Y} \quad=$ Etos Kerja Karyawan

$\mathrm{Z}=$ Kompensasi

$\mathrm{X}=$ Kebijakan Perusahaan

$\mathrm{b}_{1}, \mathrm{~b}_{2} \quad=$ Koefisien regresiberganda

$\mathrm{e}_{1}, \mathrm{e}_{2} \quad=$ Error

Pengujian terhadap hipotesis dilakukan dengan menggunakan uji statistik t, yaitu pengujian koefisien secara parsial untuk mengetahui pengaruh secara sendiri-sendiri dari setiap variabel independen terhadap variabel dependennya. Untuk menguji pengaruh bersama (multiple) digunakan uji F.

\section{PEMBAHASAN}

\section{Uji Instrumen Data}

\section{a. Uji Validitas}

Hasil uji validitas untuk variabel kebijakan perusahaan (X), Etos Kerja (Y) dan Kompensasi (Z) terhadap 30 pernyataan yang terdapat di dalam kuisioner yang disebarkan kepada karyawan KAP Drs. Chandra Dwiyanto di Surabaya diperoleh nilai $r_{\text {hitung }}$ lebih besar dari nilai $r_{\text {tabel }}$ sebesar 0,308 sehingga dianggap valid.

Berdasarkan hasil uji validitas terhadap 10 pernyataan yang terdapat di dalam kuisioner yang disebarkan kepada karyawan KAP Drs. Chandra Dwiyanto di Surabaya diperoleh nilai $r_{\text {hitung }}$ antara 0.516 sampai dengan 0.732 yang lebih besar dari nilai $r_{\text {tabel }}$ sebesar 0.308 sehingga 10 pernyataan dianggap valid.

Berdasarkan hasil uji validitas terhadap 10 pernyataan yang terdapat di dalam kuisioner yang disebarkan kepada karyawan KAP Drs. Chandra Dwiyanto di Surabaya diperoleh nilai $\mathrm{r}_{\text {hitung }}$ antara 0.617 sampai dengan 0.839 yang lebih besar dari nilai $r_{\text {tabel }}$ sebesar 0.308 sehingga 10 pernyataan dianggap valid.
Tabel 2

Hasil Uji Validitas Variabel Etos Kerja (Y)

\begin{tabular}{cccc}
\hline Pernyataan & $\begin{array}{c}\text { Koefisien } \\
\text { korelasi } \\
(\mathbf{r})\end{array}$ & $\begin{array}{c}\text { Nilai } \\
\mathbf{r} \\
\text { tabel }\end{array}$ & Penilaian \\
\hline Y -1 & 0.836 & 0.308 & Valid \\
\hline Y -2 & 0.839 & 0.308 & Valid \\
\hline Y -3 & 0.772 & 0.308 & Valid \\
\hline Y -4 & 0.680 & 0.308 & Valid \\
\hline Y -5 & 0.655 & 0.308 & Valid \\
\hline Y -6 & 0.698 & 0.308 & Valid \\
\hline Y -7 & 0.617 & 0.308 & Valid \\
\hline Y -8 & 0.536 & 0.308 & Valid \\
\hline Y -9 & 0.736 & 0.308 & Valid \\
\hline Y -10 & 0.736 & 0.308 & Valid \\
\hline
\end{tabular}

Tabel 3

Hasil Uji Validitas Variabel Kompensasi (Z)

\begin{tabular}{cccc}
\hline Pernyataan & $\begin{array}{c}\text { Koefisien } \\
\text { korelasi } \\
\text { (r) }\end{array}$ & $\begin{array}{c}\text { Nilai } \\
\mathbf{r} \\
\text { tabel }\end{array}$ & Penilaian \\
\hline $\mathrm{Z}-1$ & 0.733 & 0.308 & Valid \\
\hline $\mathrm{Z}-2$ & 0.475 & 0.308 & Valid \\
\hline $\mathrm{Z}-3$ & 0.698 & 0.308 & Valid \\
\hline $\mathrm{Z}-4$ & 0.734 & 0.308 & Valid \\
\hline $\mathrm{Z}-5$ & 0.551 & 0.308 & Valid \\
\hline $\mathrm{Z}-6$ & 0.766 & 0.308 & Valid \\
\hline $\mathrm{Z}-7$ & 0.711 & 0.308 & Valid \\
\hline $\mathrm{Z}-8$ & 0.436 & 0.308 & Valid \\
\hline $\mathrm{Z}-9$ & 0.812 & 0.308 & Valid \\
\hline $\mathrm{Z}-10$ & 0.767 & 0.308 & Valid \\
\hline
\end{tabular}

Berdasarkan hasil uji validitas terhadap 10 pernyataan yang terdapat di dalam kuisioner yang disebarkan kepada karyawan KAP Drs. Chandra Dwiyanto di Surabaya diperoleh nilai $r_{\text {hitung }}$ antara 0.436 sampai dengan 0.812 yang lebih besar dari nilai $r_{\text {tabel }}$ sebesar 0.308 sehingga 10 pernyataan dianggap valid.

\section{b. Uji Reliabilitas}

Berikut adalah hasil uji reliabilitas pada instrumen penelitian yang digunakan dalam penelitian ini.

Tabel 4

Hasil Uji Reliabilitas

\begin{tabular}{cccl}
\hline No & Variabel & $\begin{array}{c}\text { Cronbach } \\
\text { Alpha }\end{array}$ & Keterangan \\
\hline 1 & $\mathrm{X}$ & 0.802 & RELIABEL \\
\hline 2 & $\mathrm{Y}$ & 0.894 & RELIABEL \\
\hline 3 & $\mathrm{Z}$ & 0.869 & RELIABEL \\
\hline
\end{tabular}


Dari hasil pengujian tersebut dapat diketahui bahwa nilai dari Cronbach Alpha dari masingmasing variabel yang menjadi instrumen dalam penelitian ini lebih dari 0,70 sehingga dapat disimpulkan dalam penelitian ini adalah reliable.

\section{Regresi Linier Berganda}

Untuk mengetahui seberapa besar pengaruh variabel-variabel bebas yaitu $(\mathrm{X}),(\mathrm{Z})$, terhadap variabel terikat $(\mathrm{Y})$ yaitu, digunakan analisis regresi linier berganda dan hasil regresi dapat dilihat di tabel 5 dibawah ini:

\section{Tabel 5}

Hasil Regresi Linier Berganda

\begin{tabular}{cccc}
\hline Model & $\begin{array}{c}\text { Unstandardized } \\
\text { Coefficients } \\
(\mathbf{B})\end{array}$ & $\mathbf{t}$ & Sig \\
\hline Constant & 1,072 & 1,199 & 0,041 \\
\hline ratax & 0,738 & 3,640 & 0,001 \\
\hline
\end{tabular}

Berdasarkan Tabel 5 di atas diperoleh persamaan sebagai berikut:

$\mathrm{Z}=\alpha+\mathrm{b}_{1} \mathrm{X}+\mathrm{e}_{1}$

$\mathrm{Z}=1.072+0.167 \mathrm{X}+\mathrm{e}$

Tabel 6

Hasil Regresi Linier Berganda

\begin{tabular}{cccc}
\hline Model & $\begin{array}{c}\text { Unstandardized } \\
\text { Coefficients } \\
(\mathbf{B})\end{array}$ & $\mathbf{t}$ & Sig \\
\hline Constant & $-1,394$ & $-2,116$ & 0,041 \\
\hline Rata X & 0,443 & 2,612 & 0,013 \\
\hline Rata Z & 0,865 & 7,466 & 0,000 \\
\hline
\end{tabular}

$\mathrm{Y}=\mathrm{\alpha}+\mathrm{b}_{2} \mathrm{Z}+\mathrm{b}_{1} \mathrm{X}+\mathrm{e}_{2}$

$\mathrm{Y}=-1.394+0.443 \mathrm{Z}+0.865 \mathrm{X}+\mathrm{e}$

Setelah dilakukan pengujian kualitas data terhadap kuesioner dilanjutkan dengan melakukan pengujian asumsi klasik khusus untuk uji normalitas data.Hal ini diperlukan untuk menentukan uji yang tepat dalam melihat perbedaan kedua sistem sesuai dengan hipotesis yang dibentuk. Adapun hasil pengujian normalitas data adalah sebagai berikut:

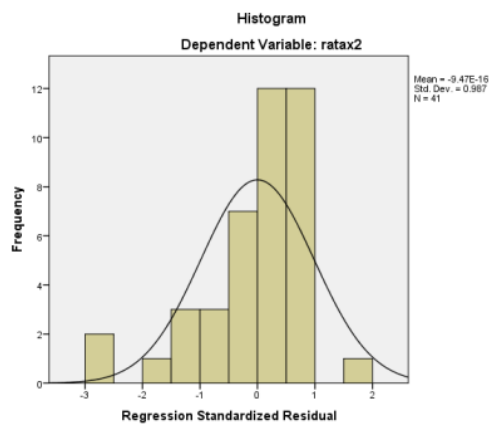

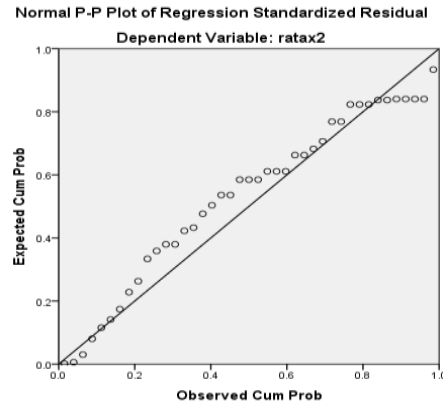

Pada uji normalitas regresi linier berganda yang kedua juga memiliki pola penyebaran memiliki garis normal kurva maka dapat dikatakan data distribusi normal.

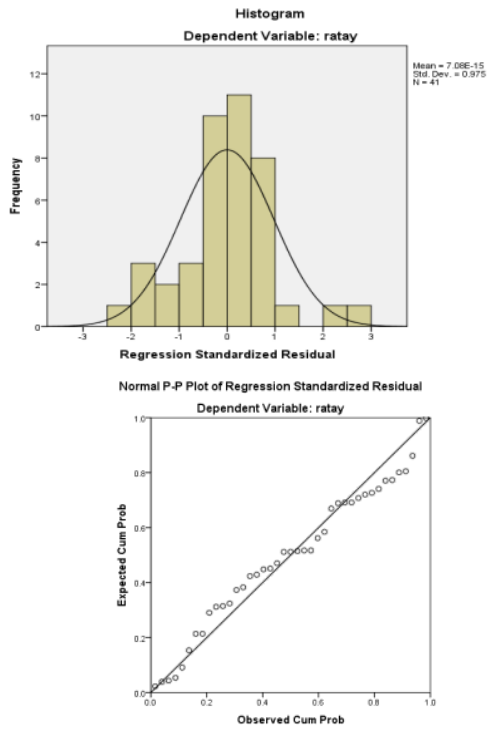

Pada uji normalitas regresi linier berganda yang kedua juga memiliki pola penyebaran memiliki garis normal kurva maka dapat dikatakan data distribusi normal.

Pengaruh langsung yaitu pengaruh kebijakan perusahaan terhadap kompensasi adalah sebesar 0,548 bersifat positif signifikan begitu juga dengan pengaruh langsung antara kompensasi terhadap etos kerja adalah sebesar 0,563 bersifat positif signifikan. Sementara itu pengaruh langsung antarakebijakan perusahaan terhadap etos kerja adalah sebesar 0,195 bersifat positif signifikan. 
Tabel 7

Pengujian Hipotesis

\begin{tabular}{lll}
\hline \multicolumn{2}{c}{ LINTASAN } & KOEFISIEN \\
\hline $\begin{array}{l}\text { Kebijakan } \\
\begin{array}{l}\text { Perusahaan } \\
(\mathrm{X})\end{array}\end{array}$ & $\begin{array}{l}\text { Kompensasi } \\
(\mathrm{Z})\end{array}$ & 0.504 \\
\hline & Etos Kerja & 0.248 \\
$\begin{array}{l}\text { Kompensasi } \\
(\mathrm{Z})\end{array}$ & $(\mathrm{Y})$ & \\
\hline $\begin{array}{l}\text { Kebijakan } \\
\begin{array}{l}\text { Perusahaan } \\
(\mathrm{X})\end{array}\end{array}$ & Etos Kerja & 0.710 \\
\hline
\end{tabular}

Pengaruh kebijakan perusahaan terhadap kompensasi adalah bersifat positif yang berarti menunjukkan hubungan searah yaitu apabila kebijakan perusahaan semakin bagus maka kompensasi akan semakin bagus. Dengan demikian hipotesis pertama penelitian (H1) yang menduga kebijakan perusahaan berpengaruh terhadap kompensasi terbukti kebenarannya. Hal ini berarti bahwa dalam penilaian karyawan, kebijakan perusahaan sudah terlaksana dengan baik.Pengaruh langsung antara kompensasi terhadap etos kerja bersifat positif signifikan.Pengaruh bersifat positif berarti menunjukkan hubungan searah yaitu apabila kompensasi semakin tinggi maka etos kerja juga akan semakin meningkat. Hal ini menunjukkan bahwa karyawan dengan kompensasi tinggi cenderung memiliki etos kerja yang tinggi pula, dan sebaliknya karyawan yang prestasinya rendah dimungkinkan karena kompensasinya juga rendah. Pengaruh kebijakan perusahaan terhadap etos kerja adalah sebesar 0,710 bersifat positif juga yang berarti menunjukkan hubungan searah yaitu apabila kebijakan perusahaan semakin bagus maka etos kerjakaryawan akan semakin bagus. Dengan demikian hipotesis kedua penelitian (H2) yang menduga kebijakan perusahaan berpengaruh terhadap etos kerja terbukti kebenarannya. Pengaruh antara kebijakan perusahaan terhadap etos kerja sebesar 0,710dan bersifat positif berarti menunjukkan hubungan yang searah yaitu apabila kebijakan perusahaan dan kompensasi semakin bagus maka etos kerja akan semakin bagus.

\section{PENUTUP}

\section{KESIMPULAN}

Berdasarkan pada penelitian yang telah dilakukan, maka dapat ditarik beberapa kesimpulan sebaga berikut:

1. Pengaruh kebijakan perusahaan terhadap kompensasi belajar adalah sebesar 0,504 bersifat positif signifikan. Pengaruh bersifat positif yang berarti menunjukkan hubungan searah yaitu apabila kebijakan perusahaan semakin bagus maka kompensasi akan semakin bagus. Dengan demikian kebijakan perusahaan berpengaruh terhadap kompensasiterbukti kebenarannya.

2. Pengaruh langsung antara kompensasi terhadap etos kerja adalah sebesar 0,248 bersifat positif signifikan. Pengaruh bersifat positif berarti menunjukkan hubungan searah yaitu apabila kompensasi semakin tinggi maka etos kerjajuga akan semakin bagus. Dengan demikian hipotesis penelitian yang menduga kompensasi berpengaruh signifikan terhadap etos kerja terbukti kebenarannya.

3. Pengaruh langsung yaitu pengaruh kebijakan perusahaan terhadap etos kerja adalah sebesar 0,710 bersifat positif signifikan. Pengaruh bersifat positif juga yang berarti menunjukkan hubungan searah yaitu apabila kebijakan perusahaan semakin baik maka etos kerja akan semakin tinggi. Dengan demikian kebijakan perusahaan berpengaruh terhadap etos kerja terbukti kebenarannya.

\section{Saran}

Berdasarkan pada penelitian yang telah dilakukan, maka saran yang dapat diberikan adalah sebagai berikut:

1. Dengan melihat kesimpulan yang ada, disarankan kepada KAP Drs. Chandra Dwiyanto untuk terus melakukan tinjauan terhadap kebijakan perusahaannya sehingga mampu meningkatkan etos kerja karyawan.

2. KAP Drs. Chandra Dwiyanto juga diharapkan selal melakukan evaluasi terhadap sistem kompensasi serta dilakukan penyesuaian terhadap sistem kompensasi tersebut.

3. Diharapkan untuk penelitian selanjutnya menambahkan atau mengganti variabel lainnya yang berkaitan dengan etos kerja, antara lain pelatihan kerja, kepuasan kerja, dan penghargaan.

\section{DAFTAR PUSTAKA}

Anggri, P. Sari, 2012, Penerapan Etos Kerja Pegawai pada Stasiun KIPM Kelas II Bengkulu, Ekombis Review.

Fakhri, Faiq, Risha, 2015, Pengaruh Kompensasi dan Pelatihan Terhadap Kinerja Karyawan dengan Kepuasan Kerja sebagai Variabel Intervening, Skripsi 
Mahasiswa S1 Fakultas Ekonomika dan Bisnis, Universitas Diponegoro Semarang.

Ghozali, Imam, 2013, Aplikasi Analisis Multivariate dengan Program SPSS, Badan Penerbit Undip.

Hastuti Sri, 2013, Pengaruh Komunikasi, Kompensasi dan Etos Kerja terhadap Kinerja Pegawai Koordinator Unit Pelaksana Teknis Dinas Pendapatan Provinsi Jawa Timur di Probolinggo, Tesis Mahasiswa S2 Program Studi Magister Manajemen ,Program Magister Fakultas Ekonomi Universitas Jember.

http://abidshoftskill.blogspot.co.id/2015/04/kewaji ban-karyawan-dan-perusahaan.html,

"Kewajiban Karyawan dan Perusahaan". Diakses April 2015.

http://definisibisnismenurutparaahli.blogspot.co.id/ 2016/09/10-definisi-perusahaan-menurutpara-ahli.html, "Definisi Perusahaan menurut para ahli". Diakses 10 September 2016.

http://fekool.blogspot.co.id/2014/11/kompensasidan-karakteristik.html, "Kompensasi dan Karakteristik". Diakses November 2014.

http://fekool.blogspot.co.id/2016/10/teorikompensasi-gary-dessler.html, "Teori

Kompensasi”. Diakses Oktober 2016.

http://infodanpengertian.blogspot.co.id/2015/04/pe ngertian-kebijakan-menurut-para-ahli.html, "pengertian-kebijakan-menurut-paraahli". Diakses April 2015

http://jurnal-sdm.blogspot.co.id/2009/07/teorikompensasi.html, "Teori Kompensasi". Diakses Juli 2009.

http://jurnal-sdm.blogspot.co.id/2010/10/etoskerja-definisi-fungsi-dan-cara.html, "Etos Kerja dan Definisi, Fungsi serta Cara Etos Kerja". Diakses Oktober 2010.

http://nasihatbathin.blogspot.co.id/2011/12/etoskerja-pegawai.html, "Etos Kerja Pegawai“. Diakses Desember 2011.

http://sujudmm.blogspot.co.id/2011/02/membangu n-etos-kerja-yang-unggul.html, "Membangun Etos Kerja yang Unggul".

http://wahyudiantoeko.blogspot.co.id/2011/01/teorikebijakan.html, "Teori Kebijakan". Diakses Januari 2011.

http://www.dosenpendidikan.com/9-pengertianperusahaan-menurut-para-ahli-lengkap/ http://www.kajianpustaka.com/2012/10/pengertian -jenis-dan-tujuan-kompensasi.html, "Pengertian, Jenis dan Tujuan Kompensasi”. Diakses Oktober 2012.

http://www.kajianpustaka.com/2016/09/pengertian -ciri-dan-menumbuhkan-etos-kerja.html, "Pengertian, Ciri dan Menumbuhkan Etos Kerja”. Diakses September 2016.

http://www.pengertianahli.com/2014/08/pengertian -kebijakan-menurut-paraahli.html, "pengertian-kebijakan-menurutpara-ahli." Diakses Agustus 2014.

http://www.pengertianahli.com/2013/11/pengertian -perusahaan-jenis-perusahaan.html, "Pengertian Perusahaan dan Jenis Perusahaan". Diaskses November 2013.

http://www.putra-putri-indonesia.com/pengertianetos-kerja.html dipublish oleh Judika Malau (Trainer), Motivator dan Konsultan Bisnis.

https://badriah27.wordpress.com/2012/11/07/buda ya-kerja-etos-kerja/, "Budaya Kerja dan Etos Kerja”. Diakses 7 November 2012.

https://cmaconsultancynservices.wordpress.com/ve rifikasii/kebijakan/contoh-kebijakan/

https://kanglondo.wordpress.com/2013/01/09/hum anisme-dalam-kebijakan-perusahaan/, "Humanisme dalam Kebijakan Perusahaan”. Diakses 9 Januari 2013.

Kadarisman. M, 2012, Manajemen Kompensasi, Penerbit PT.Rajagrafindo Persada, Jakarta.

Mondy, R.Wayne,2008,Manajemen Sumber Daya Manusia,Jilid 2,Edisi 10, Penerbit Erlangga,Jakarta.

Nurcahyani Ni Made, Adnyani Dewi IGA, 2016, Pengaruh Kompensasi dan Kompensasi terhadap Kinera Karyawan dengan Kepuasan Kerja sebagai variabel Intervening , E-Journal Management Unud, vol.5,No.1, 2016.

Retnosari Intan dkk, 2016, Pengaruh sistem Kerja Kontrak, Kompensasi, dan Career Path terhadap Corporate Performance dengan Kinerja Karyawan sebagai variabel Intervening, Journal of Management, Vol 2, No.2, 2016.

Sugiyono, 2012, Metode Penelitian Bisnis, Penerbit CV. Alfabeta Bandung.

Sumarsono, 2007, Metode Penelitian Akuntansi (Beberapa contoh Interpretasi hasil pengolahan data), Penerbit Unesa University Press. 